\title{
Habitat Kelelawar Pemakan Buah (Penthetor lucassi) Di Hutan Bukit Beluan Kecamatan Hulu Gurung Kabupaten Kapuas Hulu
}

\author{
Sri Sumarni \\ Fakultas Pertanian Univesitas Kapuas Sintang \\ Email sri_nanisumarni@yahoo.co.id
}

\begin{abstract}
Abstrak : Kelelawar pemakan buah (Penthetor lucasii) merupakan salah satu mamalia yang ada di kawasan hutan Bukit Beluan Kecamatan Hulu Gurung Kabupaten Kapuas Hulu. Kelelawar memiliki peran penting dalam ekologi hutan, sehingga keberadaannya di alam harus dilindungi terutama habitatnya. Metode penelitian yang digunakan deskriptif dengan teknik observasi. Habitat merupakan tempat hidup dan berkembangnya kelelawar, dan gua menjadi salah satu habitat tempat beristirahat pada siang hari. Gua di kawasan hutan Bukit Beluan sebagai habitat kelelawar dengan karakteristik terowongan dengan tinggi $6 \mathrm{~m}$, panjang gua lebih kurang $70 \mathrm{~m}$, lebar mulut gua $33,8 \mathrm{~m}$ dan lantai gua sedikit berkarang. Aliran sungai kecil sepanjang lebih kurang $20 \mathrm{~m}$ di dalam gua dan aliran sungai yang lebih pendek terdapat di mulut gua. Rata-rata suhu di dalam gua $25,23^{\circ} \mathrm{C}$ dengan kelembaban $90 \%$. Vegetasi yang ada disekitar gua adalah Langsat, durian, engkuis (lengkeng hutan), puak (tampoi), jenis nangka-nangkaan, rambai, empakan (pekawai). Jenis satwa lain yang ditemui dalam gua adalah ular, cicak sedangkan di sekitar gua kura-kura, labi-labi, lele dan laba-laba.
\end{abstract}

\section{PENDAHULUAN}

Kabupaten Kapuas Hulu
merupakan salah satu wilayah di
Kalimantan Barat yang memiliki
sumber daya alam yang melimpah.

Kondisi fisiografi Kapuas Hulu menjadikan daerah ini memiliki tingginya keanekaragaman jenis endemik Kalimantan, dan ditetapkan kabupaten konservasi berdasarkan SK Bupati Nomor 144 Tahun 2003. Selain kekayaan jenis, disini juga terdapat ekosistem perairan (danau, sungai) dan pegunungan. Sampai saat ini pengelolaan kawasankawasan konservasi dilakukan oleh pemerintah, tetapi di beberapa tempat di kabupaten ini pengelolaan kawasan hutan dilakukan oleh masyarakat setempat. Salah satunya adalah kawasan hutan Beluan Kompleks yaitu berupa hamparan hutan yang terdiri Bukit Capan, Bukit Beluan dan Bukit Piabung, dengan ketinggian $238 \mathrm{~m}$ sampai dengan lebih kurang $1.151 \mathrm{~m}$ diatas 
Habitat Kelelawar Pemakan Buah (Penthetor lucassi) Di Hutan Bukit Beluan Kecamatan Hulu Gurung Kabupaten Kapuas Hulu

permukaan laut. Namun hingga saat ini berdasarkan informasi hasil wawancara dan data yang tersedia untuk luasan kawasan berhutan ini belum diketahui secara pasti. Akan tetapi upaya-upaya konservasi terus dilakukan semaksimal mungkin untuk menjaga kelestarian nilai sumber daya alam yang terdapat di kawasan hutan tersebut. Sumber daya alam yang terdapat di kawasan ini tidak hanya tumbuhan dan satwa tetapi juga nilai keindahan alam. Keanekaragaman hayati tersebut berupa Amorphopallus, pohon buahbuahan (lengkeng hutan, durian, puak) dan lain sebagainya. Sementara untuk satwa jenis-jenis Anura, Landak, Kura-kura (Notochelys platynota) termasuk jenis kelelawar yang banyak dijumpai dikawasan ini.

Kelelawar merupakan mamalia yang dapat terbang yang jumlahnya di dunia mencapai 18 famili, sekitar 192 genus dan 977 spesies kelelawar. Jumlah jenisnya merupakan kedua terbesar sesudah ordo binatang pengerat (Rodentia) dalam kelas Mammalia (Nowak, 1983 dalam Suyanto, 2001). Secara langsung peranan jenis kelelawar pemakan buah dalam ekosistem hutan sebagai penyerbuk bunga (polinator) dan pemencar biji serta penyubur tanah (dari kotoran). Salah satu jenis kelelawar pemakan buah adalah Penthetor lucasii yang penyebarannya di Kalimantan.

Walaupun pemanfaatan kelelawar masih sebatas sebagai bushmeat untuk konsumsi masyarakat lokal, namun dikhawatirkan populasinya akan semakin menurun. Hal ini dikarenakan aktifitas manusia seperti perburuan, penebangan pohon sebagai pakan kelelawar, semakin berkurangnya luasan hutan akibat alih fungsi. Oleh sebab itu upayaupaya konservasi terus dilakukan melalui kegiatan sosialisasi maupun penelitian terhadap aspek-aspek yang berkaitan dengan spesies. Untuk saat ini informasi tentang tipe habitat, vegetasi sekitar serta kondisi iklim setempat yang menunjang keberadaan kelelawar yang masih belum diketahui. Penelitian ini bertujuan untuk mengetahui karakteristik habitat kelelawar 
Habitat Kelelawar Pemakan Buah (Penthetor lucassi) Di Hutan Bukit Beluan Kecamatan Hulu Gurung Kabupaten Kapuas Hulu

pemakan buah (Penthetor lucasii) di Hutan Bukit Beluan.

\section{METODE PENELITIAN}

Penelitian dilakukan di kawasan berhutan Bukit Beluan Kecamatan Hulu Gurung Kabupaten Kapuas Hulu. Obyek penelitian adalah habitat kelelawar pemakan buah (Penthetor lucasii). Metode yang digunakan dalam penelitian ini adalah deskriptif dengan teknik observasi. Survey awal dilakukan sebelum pelaksanaan penelitian dengan melihat dan meninjau kondisi umum lokasi penelitian dan gua yang merupakan habitat dari kelelawar tersebut.

Variabel yang diamati adalah kondisi di luar gua antara lain vegetasi disekitar gua, suhu dan kelembaban, ketinggian tempat dan satwa yang ada di sekitar, habitat di dalam gua yang meliputi karakteristik gua, suhu dan kelembaban, kondisi dalam gua, jenis satwa lain.

Alat yang digunakan GPS Garmin eTrex 10, Kompas Sunto, Termohygro, Perlengkapan untuk pengamatan vegetasi, tally sheet, parang rintis, pita meter dan pita ukur.

\section{HASIL PENELITIAN}

Kelelawar jenis ini memiliki tubuh bagian atas (punggung) coklat abu-abu tua, bagian bawah (dada) abu-abu pucat.bagian atas kepala sering jelas terlihat lebih gelap di bagian pertengahan dan lebih pucat di dekat mata bagian tepi telinga gelap dan hanya ada sepasang gigi seri bawah.

Klasifikasi kelelawar jenis codot kecil kelabu (Phentetor lucasii).

$\begin{array}{ll}\text { Kerajaan } & \text { : Animalia } \\ \text { Filum } & \text { : Chordata } \\ \text { Kelas } & \text { : Mamalia } \\ \text { Ordo } & \text { : Chiroptera } \\ \text { Sub Ordo } & : \\ \text { Megachiroptera } & \\ \text { Famili } & \text { : Pteropodidae } \\ \text { Genus } & \text { : Penthetor } \\ \text { Jenis } & : \quad \text { Penthetor } \\ \text { lucasii } & \end{array}$

Nama Indonesia $\quad$ : Codot kecil kelabu

Kelelawar dengan berat 30-44 gram, panjang kepala sampai tubuh 14-16 
Habitat Kelelawar Pemakan Buah (Penthetor lucassi) Di Hutan Bukit Beluan Kecamatan Hulu Gurung Kabupaten Kapuas Hulu

$\mathrm{mm}$, lengan bawah 55-62 mm, dan

ekor $8-13 \mathrm{~mm}$. Tubuh bagian atas berwarna coklat abu-abu tua, pada bagian bawah abu-abu pucat, bagian atas kepala lebih gelap sementara dari bagian perut pada ekor dan lebih pucat didekat mata, tetapi telinganya gelap.

\section{Habitat}

Habitat satwa liar adalah lingkungan tempat hidup dan berkembangnya secara alami. Umumnya habitat kelelawar berada dari pantai sampai pegunungan pada gua, batu-batu karang, pohon-pohon dan dialam terbuka. Kelelawar melakukan aktivitasnya pada malam hari, sedangkan pada siang hari digunakan untuk beristirahat dengan tidur bergelantung terbalik di dalam gua-gua ataupun pada pepohon tertentu.

Kelelawar buah (Penthetor lucasii) atau codot kecil kelabu memiliki tubuh bagian atas (punggung) coklat abu-abu tua, bagian bawah (dada) abu-abu pucat.bagian atas kepala sering jelas terlihat lebih gelap di bagian pertengahan dan lebih pucat di dekat mata bagian tepi telinga gelap dan hanya ada sepasang gigi seri bawah. Kelelawar ini menggunakan gua sebagai habitat untuk tempat beristirahat pada siang hari sedangkan menjelang malam hari kelelawar tersebut keluar untuk mencari makan.

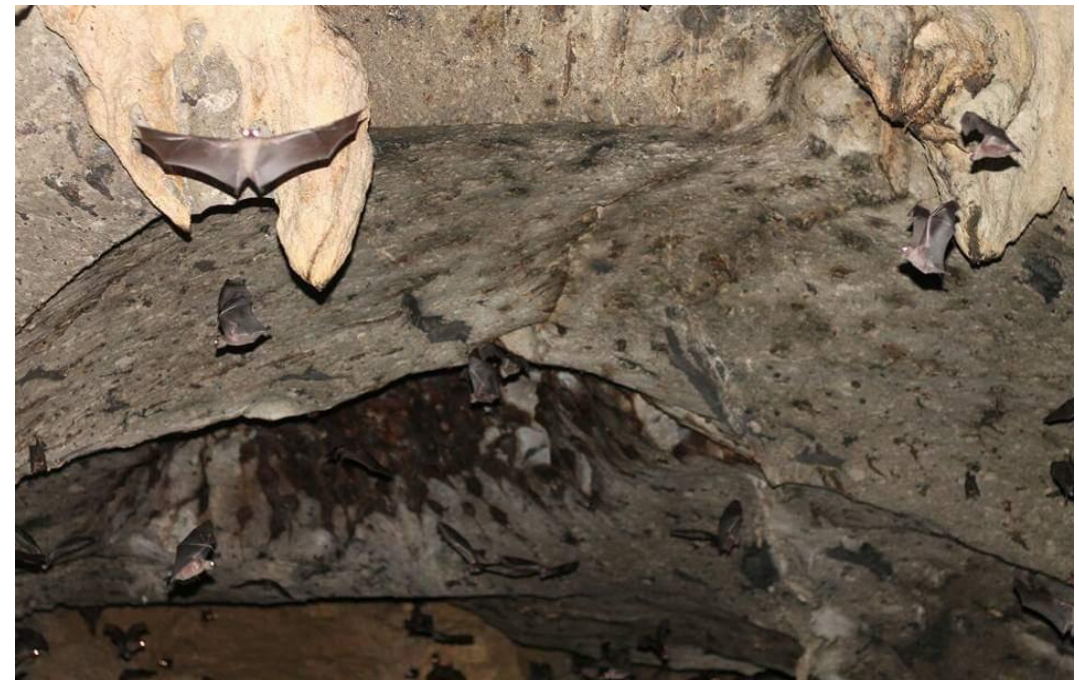

Gambar 1. Habitat kelelawar (Penthetor lucasii) di Bukit Beluan 
Habitat Kelelawar Pemakan Buah (Penthetor lucassi) Di Hutan Bukit Beluan Kecamatan Hulu Gurung Kabupaten Kapuas Hulu

Pengamatan dilakukan pada dua kondisi yaitu karakteristik gua dan habitat di sekitar gua. Ini sesuai dengan pendapat (Shawn, 1985) bahwa komponen habitat yang mengendalikan kehidupan satwa liar terdiri atas Pakan (food), sedangkan ketersediaan pakan erat hubungannya dengan perubahan musim; Pelindung (cover), Air (water), dan Ruang (space), dibutuhkan oleh individu \pm individu satwa untuk mendapatkan cukup pakan, pelindung, air dan tempat untuk kawin.
Berdasarkan hasil observasi di kawasan hutan Bukit Beluan terdapat salah satu gua yang digunakan oleh kelelawar buah (Penthetor lucasii) untuk tempat istirahat. Keberadaan gua ini sangat mendukung untuk populasi kelelawar. Gua memiliki terowongan dengan tinggi 6 meter, panjang gua lebih kurang 70 meter, lebar mulut gua $33,8 \mathrm{~m}$ dan lantai gua sedikit berkarang serta terdapat aliran sungai kecil sepanjang lebih kurang $23 \mathrm{~m}$ di bagian dalam dan aliran sungai di depan mulut gua.

\section{Habitat di dalam Gua}

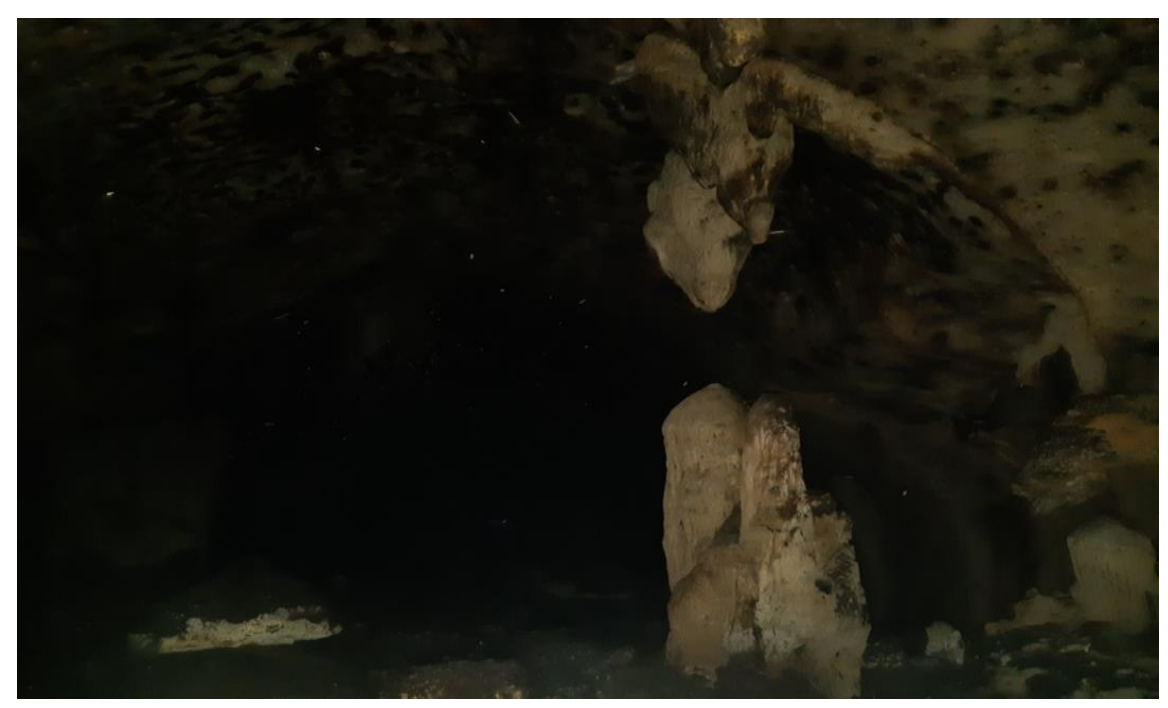

Gambar 2. Kondisi bagian dalam gua

Kondisi iklim mikro di dalam gua merupakan faktor pendukung keberadaan kelelawar dan satwa liar lainnya yang ada di dalam gua. Kondisi iklim mikro tersebut dapat dilihat pada tabel berikut. 
Habitat Kelelawar Pemakan Buah (Penthetor lucassi) Di Hutan Bukit Beluan Kecamatan Hulu Gurung Kabupaten Kapuas Hulu

Tabel 1. Kondisi iklim mikro di dalam gua

No. Waktu Pengukuran Temperatur $\left({ }^{\circ}\right.$ Celcius $) \quad$ Kelembaban (\%)

$\begin{array}{llll}1 & \text { Pagi } & 24,8^{\circ} & 90 \\ 2 & \text { Siang } & 25,8^{\circ} & 89 \\ 3 & \text { Sore } & 25,1^{\circ} & 91 \\ & \quad \text { Rata-rata } & 25,23 & 90\end{array}$

Pada Tabel 1 menunjukkan bahwa habitat kelelawar buah (Penthoter rata-rata temperatur di dalam gua lucasii) di dalam gua. Menurut adalah $25,23^{\circ} \mathrm{C}$, sedangkan rataFatern dkk (2006) vegetasi di sekitar rata kelembaban di dalam gua $90 \%$. Temperatur rata-rata di luar gua adalah $24,5^{\circ} \mathrm{C}$ dengan kelembaban $86 \%$.

\section{Habitat di sekitar Gua}

a. Vegetasi

gua merupakan aspek habitat lain yang menentukan keberadaan kelelawar di dalam gua adalah tipe vegetasi sekitar. Berdasarkan hasil pengamatan vegetasi yang berada di sekitar gua dapat di lihat pada Tabel 2 berikut ini.

Vegetasi sekitar gua merupakan satu bagian faktor lingkungan terhadap

Tabel 2. Jenis vegetasi sekitar Gua Bukit Beluan

No. Nama lokal

Nama Ilmiah

Famili

1. Durian

Durio zibethinus

Bombacaceae

2. Engkuis (lengkeng hutan)

Dimocarpus longan

Sapindaceae

3. Langsat

Buchanania

Anacardiaceae

4. Pelaik

arborescens

5. Kepuak

Alstonia anguisteloba

Apocynaceae

Artocarpus sp

Moraceae

6. Empakan/pekawai

Durio kuteijiensis

Bombacaceae

7. Rambai

Baccaurea

Euphorbiaceae

8. Puak (tampoi)

montleyana

Baccaurea

Euphorbiaceae

macrocarpa

Sumber : Hasil Penelitian, 2019 
Habitat Kelelawar Pemakan Buah (Penthetor lucassi) Di Hutan Bukit Beluan Kecamatan Hulu Gurung Kabupaten Kapuas Hulu

\section{b. Satwa}

Satwa lain yang ditemui baik di dalam maupun diluar gua antara lain sawak, kepiting, Labi-labi, kura-kura
(Notochelys platynota), lele dan labalaba, Lebih jelasnya dapat dilihat pada tabel 3 berikut ini.

Tabel 3. Jenis-jenis satwa yang ditemukan di gua dan sekitarnya.

\begin{tabular}{lllll} 
No. & \multicolumn{1}{c}{ Nama lokal } & \multicolumn{1}{c}{ Nama Ilmiah } & \multicolumn{1}{c}{ Famili } & \multicolumn{1}{c}{ Lokasi } \\
ditemukan
\end{tabular}

Sumber : Hasil Penelitian, 2019

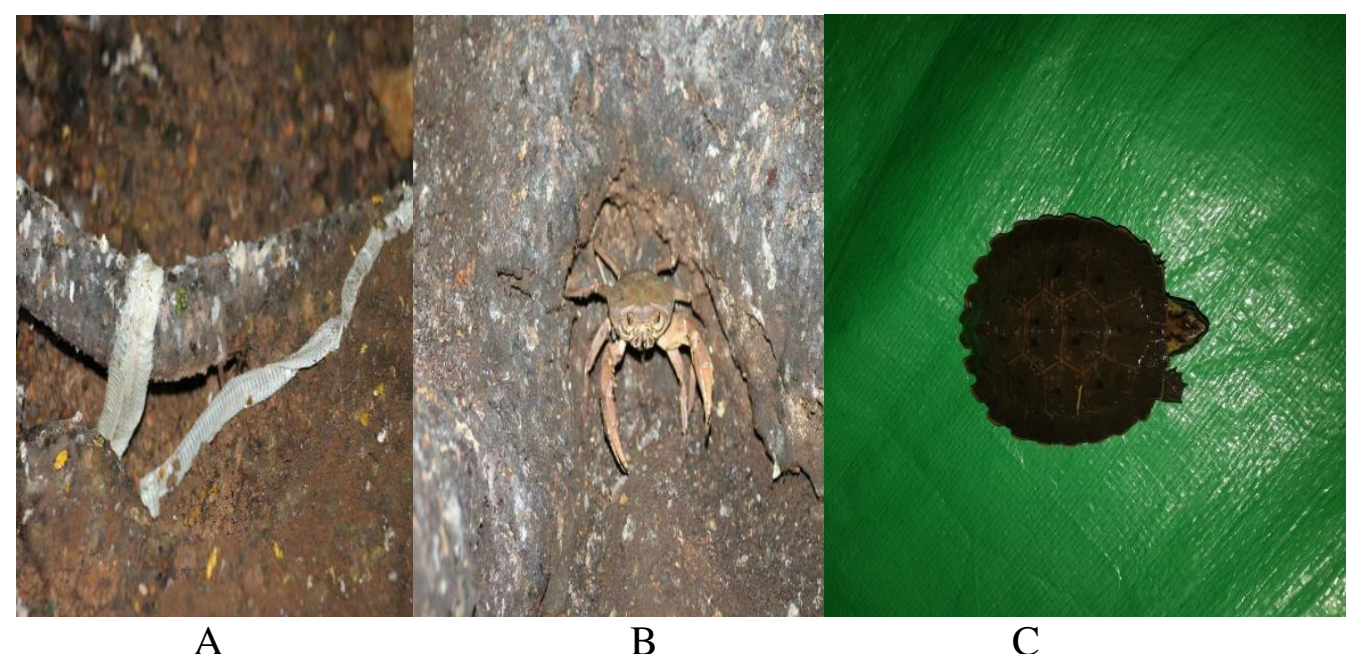

Gambar 3. Jenis satwa yang ditemukan baik di dalam maupun diluar gua a. Kulit ular ; b. Ketam/keramak; c. Kura-kura.

\section{PEMBAHASAN}

Kelelawar jenis codot kecil kelabu merupakan kelelawar pemakan buah dan biji, menempati ekologi dan habitat dengan bertengger terutama di naungan batu ataupun gua-gua, kadang dalam keadaan yang hampir gelap total, 
Habitat Kelelawar Pemakan Buah (Penthetor lucassi) Di Hutan Bukit Beluan Kecamatan Hulu Gurung Kabupaten Kapuas Hulu

makanannya dari buah dan bijibijian. Keadaan gua juga sangat gelap dan proses dekomposisi kotoran kelelawar (guano) yang menyebabkan temperatur gua sedikit lebih tinggi dari luar gua.

Keberadaan pohon sekitar gua merupakan hal penting pada habitat kelelawar pemakan buah (Penthoter lucasii) yang terdapat di gua pada Bukit Beluan, ini dikarenakan pohon yang berada di sekitar gua menjadi peneduh dan mampu menciptakan iklim mikro di sekitar gua, sehingga membuat gua menjadi habitat yang ideal untuk kelelawar. Hal serupa dikemukan oleh Risman (1996) bahwa vegetasi sekitar gua merupakan peneduh dan penutup tanah yang baik karena berpengaruh terhadap topografi yang mampu melindungi permukaan gua dari pengikisan air hujan dan resapan air yang masuk ke dalam gua. Vegetasi juga sebagai penyedia pakan bagi satwa sangatlah penting, karena setiap satwa memiliki pakan kesukaan yang berbeda. Keberagaman jenis satwa yang ditemukan selama penelitian merupakan bagian dari habitat secara biotik. Walau pun salah satu dari satwa tersebut adalah predator bagi kelelawar, hal ini sesuai dengan pendapat Fatem dkk (2006), bahwa ular merupakan predator alami yang mengganggu populasi kelelawar di dalam gua. Namun hal ini menjadi keseimbangan dalam ekosistem dan habitat tersebut, sehingga tidak terjadi peledakan populasi yang berdampak merugikan bagi alam.

\section{PENUTUP}

\section{Kesimpulan}

1. Kelelawar pemakan buah (Penthetor lucasii) di kawasan hutan Bukit Beluan Kecamatan Hulu Gurung Kabupaten Kapuas Hulu menempati gua sebagai habitat istirahat pada siang hari. Karakteristik gua ini sangat mendukung dengan terowongan setinggi lebih kurang 5 meter, panjang gua lebih kurang 70 meter, lebar mulut gua 33,8 m dan lantai gua sedikit berkarang serta terdapat aliran sungai kecil sepanjang lebih kurang $23 \mathrm{~m}$. Temperatur rata-rata di dalam gua $25,23^{\circ} \mathrm{C}$ dengan kelembaban $90 \%$. 
Habitat Kelelawar Pemakan Buah (Penthetor lucassi) Di Hutan Bukit Beluan Kecamatan Hulu Gurung Kabupaten Kapuas Hulu

2. Vegetasi yang ada di sekitar gua sebanyak 8 jenis antara lain ; durian, langsat, engkuis, empakan, puak, pulai, jenis kepuak, dan rambai.

3. Satwa yang ditemukan baik di dalam gua maupun disekitar gua adalah ular, laba-laba, kura-kura, labi-labi, kepiting dan lele, beberapa jenis serangga serta laba-laba (ordo Araneae).

\section{Saran}

Berdasarkan hasil pengamatan maka diharapkan pengelolaan kawasan hutan di kompleks Beluan lebih diperhatikan baik pada pengamanan maupun pelestarian sumber daya hutan yang merupakan potensi wilayah kecamatan Hulu
Gurung khususnya dan kabupaten Kapuas Hulu umumnya.

\section{DAFTAR PUSTAKA}

Alikodra HS. 1990. Pengelolaan Satwa Liar, Jilid I. Departemen Pendidikan dan Kebudayaan, Direktur Jenderal Perguruan Tinggi. Pusat Antar Universitas Ilmu Hayati, Bogor.
Suyanto A. 2001. Kelelawar Di Indonesia. LIPI seri Panduan Lapangan.

Payne and Francis, 2000. Mamalia Di Kalimantan, Sabah, Sarawak \& Brunei Daruss alam. Seri Panduan Lapangan. Jakarta.

Fatem, M. Bumbut, P. \& Ungirwalu, A. 2006. Habitat Kelelawar Buah (Dobsonia minnor) Di Hutan Tropis Dataran Rendah Nuni Pantai Utara Manokwari. Jurnal Media Konservasi Vol. XI, No. 1 April 2006 : 17-20. 